\title{
Habitat and nest site characteristics of Olrog's Gull Larus atlanticus breeding at Bahía San Blas, Argentina
}

\author{
PABLO YORIO, DANIEL E. RÁBANO and PABLO FRIEDRICH
}

\section{Summary}

Olrog's Gull Larus atlanticus is a vulnerable species endemic to the Argentine Atlantic coast. We present information on new breeding colonies, update information on known colonies, and describe habitat and nest site characteristics of Olrog's Gulls breeding at Bahía San Blas, southern Buenos Aires Province, Argentina. Information was obtained during the 1998 breeding season. We recorded four colonies on islets, with a total population size of 305 pairs. Colonies were located on open ground, partly bordered by vegetation. The two colonies at Islote Arroyo Jabalí Oeste were located more than $150 \mathrm{~m}$ from the high tide line, while the two colonies at Banco Nordeste were placed only a few metres from the high tide mark ( $1-6 \mathrm{~m}$ ). Most nests were located more than a metre away from low Atriplex patagonica bushes (20-30 cm high) and herbaceous species, although a few nests were a few $\mathrm{cm}$ from vegetation. Nests were built on vegetation debris, on low herbaceous vegetation, and on gravel and sand. All nests at the four colonies were built with vegetation debris, mainly Spartina densiflora and some Salicornia sp. Mean external and internal diameters of nests were $40.57 \pm 5.14$ and $19.71 \pm 2.21 \mathrm{~cm}$, respectively. Gulls nested in discrete groups at relatively high densities, which ranged between 0.62 and 1.1 nests $/ \mathrm{m}^{2}$. Nest occupation and number of eggs per nest varied among colonies. Kelp Gulls Larus dominicanus were observed nesting in close proximity to all colonies. Further studies are needed to assess habitat partitioning between these two species, particularly considering that they nest in association at all breeding locations in coastal Argentina and that Kelp Gulls have shown an important population increase in recent decades.

\section{Introduction}

Olrog's Gull Larus atlanticus is endemic to the Argentine Atlantic coast, considered as vulnerable (Collar et al. 1994) or highly threatened (Parker et al. 1996), and is included in Appendix I of the Convention on Migratory Species. This species has a relatively low breeding population, with approximately 2,100 pairs, and a restricted breeding distribution, nesting only in southern Buenos Aires and Chubut (Yorio et al. 1997). Despite its current conservation status, very little is yet known about its breeding biology and ecological requirements. Aspects of its breeding behaviour have been described by Olrog (1967), Devillers (1977) and Herrera (1997). Basic information on ecological requirements during breeding and the monitoring of existing colonies due to the observed short-term changes in colony location and population estimates are needed to develop adequate conservation and management strategies. In this paper we present information on 


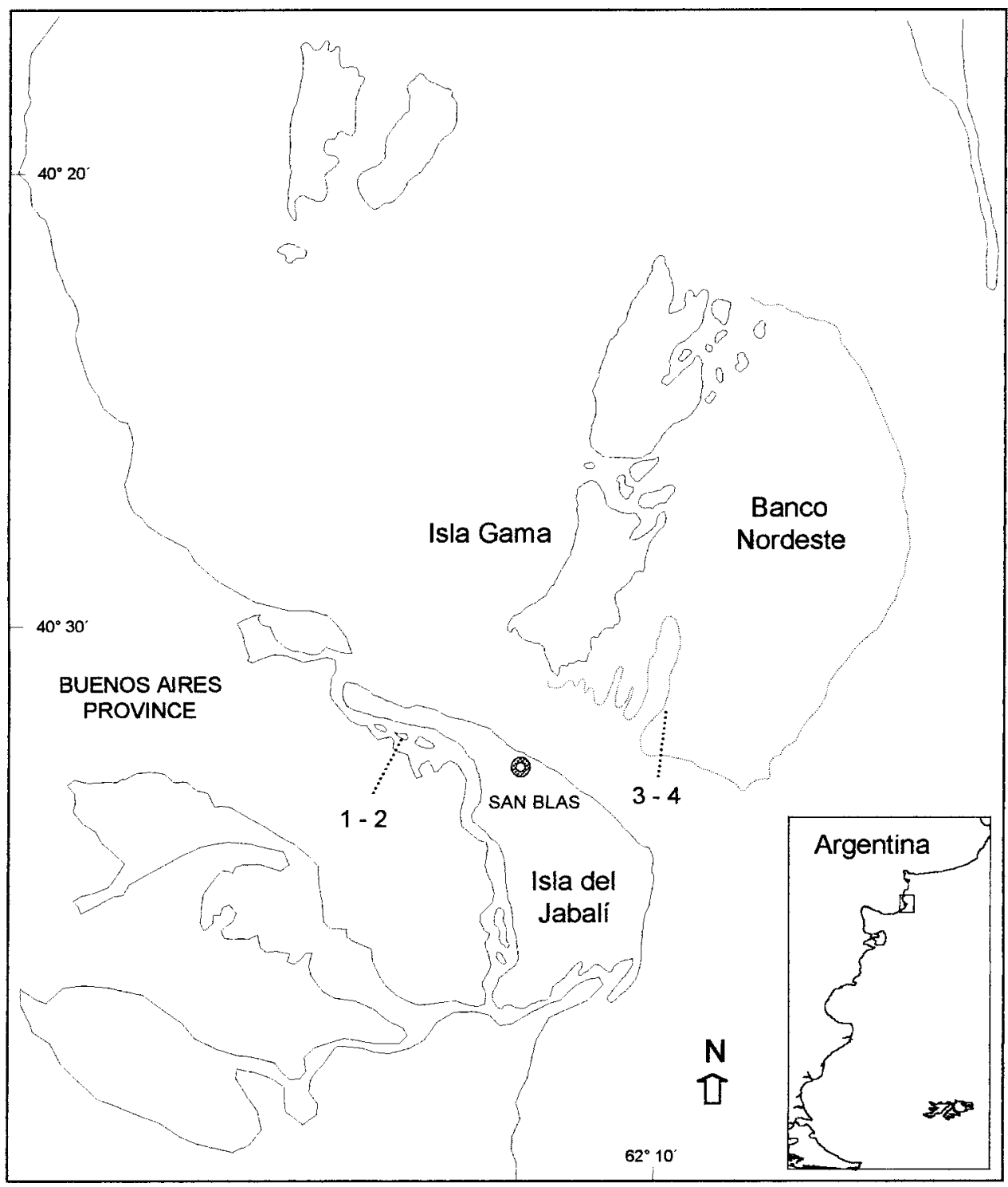

Figure 1. Location of Olrog's Gull colonies at the Bahía San Blas area, southern Buenos Aires Province, Argentina. Numbers correspond to sites in Table 1.

new breeding colonies, update information on known colonies, and describe habitat and nest site characteristics of Olrog's Gulls breeding at Bahía San Blas, southern Buenos Aires.

\section{Methods}

On 30 October 1998 we surveyed the coast and islands of Bahía San Blas, including Isla del Jabalí and adjacent islets, Isla Gama and Banco Nordeste (Figure 1) 
Table 1. Location and size of Olrog's Gull breeding colonies in Bahía San Blas, Argentina, during the 1998 breeding season

\begin{tabular}{llc}
\hline Breeding site & Location & Number of nests \\
\hline Islote Arroyo Jabalí Oeste 1 & $40^{\circ} 33^{\prime} \mathrm{S}, 62^{\circ} 16^{\prime} \mathrm{W}$ & 17 \\
Islote Arroyo Jabalí Oeste 2 & $40^{\circ} 33^{\prime} \mathrm{S}, 62^{\circ} 16^{\prime} \mathrm{W}$ & 73 \\
Banco Nordeste 1 & $45^{\circ} 4^{\prime} \mathrm{S}, 66^{\circ} 19^{\prime} \mathrm{W}$ & 29 \\
Banco Nordeste 2 & $45^{\circ} 11^{\prime} \mathrm{S}, 66^{\circ} 31^{\prime} \mathrm{W}$ & 186 \\
Total & & 305 \\
\hline
\end{tabular}

to locate Olrog's Gull colonies. We used a Piper plane, flying at an altitude of 100-300 m with observers on both sides of the plane. On 30 and 31 October 1998, we visited by boat the colonies identified in the aerial survey. We determined the size of the Olrog's Gull colonies by full nest counts. At each colony we described the vegetation and physical characteristics surrounding the colony. We measured the distance from the water, distance from the nearest vegetation, and distance to the nearest Kelp Gull Larus dominicanus nest. Given the nesting pattern of Olrog's Gulls, which breed in a single dense group, these variables were measured from the nearest Olrog's Gull nest located at the colony periphery. In addition, at each nest in all colonies we recorded the number of eggs per nest, type of nesting material, and nest substrate type. At both colonies in Islote Arroyo Jabalí Oeste and at the smaller colony at Banco Nordeste we measured nest dimensions (external and internal diameter) and distance to the nearest neighbour (centre to centre) to the nearest $\mathrm{cm}$. The area of the colony was obtained from a map showing the location of each nest, taking the limits of the colony as the line joining points distant at an average inter-nest distance, estimated for that colony, from peripheral nests. Disturbance to breeding birds was considered to be low, as gulls flew from nests only when at close range, returning to their nests soon after researchers left the colony. In addition, no predation or cannibalism was observed during visits to the colony.

\section{Results}

\section{Location and size of breeding colonies}

We located four breeding colonies, two in an islet near the mouth of Arroyo Jabalí and two at Banco Nordeste (Figure 1). Total population size for this area was estimated as 305 breeding pairs (Table 1). All colonies were associated with breeding Kelp Gulls.

\section{Habitat characteristics}

Islote Arroyo Jabali Oeste Two of the four colonies were located at Islote Arroyo Jabalí Oeste (Figure 1), the same islet where they were recorded breeding in 1990 and 1995. This islet is oval, extending approximately $600 \mathrm{~m}$ east-west and $400 \mathrm{~m}$ north-south. It is a low islet, partially covered with vegetation. At the central sector of the islet there is an elevation covered with low bushes (up to $60 \mathrm{~cm}$ high), mainly Atriplex patagonica, and herbaceous 
vegetation, such as Salicornia sp., Frankenia juniperoides and grasses. Spartina densiflora is found throughout the periphery, and between this vegetation and the bush area there is a band of sandy substrate $150-250 \mathrm{~m}$ wide, partly covered with Salicornia sp. and Limonium sp. Both of the Olrog's Gull colonies were located at the central sector of the islet, at the west (colony 1) and east (colony 2) end of the vegetation area, respectively. Kelp Gull nests were located between these two Olrog's Gull colonies.

Colonies were located on open ground, partly bordered by vegetation consisting of Atriplex patagonica, Salicornia sp. and grasses. Colony 1 was located on open ground covered by low herbaceous vegetation of Salicornia sp. and Frankenia juniperoides while colony 2 was on bare open ground covered in great extent by Spartina debris probably brought for nest building. Both colonies were located more than $150 \mathrm{~m}$ from the high tide line. Most nests were located more than a metre away from low Atriplex bushes $(20-30 \mathrm{~cm}$ high) and herbaceous species, although a few nests $(<16 \%)$ were a few centimetres from vegetation. The nearest Kelp Gull nest was located 4.9 and $1.4 \mathrm{~m}$ from colonies 1 and 2, respectively. Hollows which appeared to be old nests were observed on a nearby bare open sector a few metres away from colony 2 . This site was occupied by breeding Olrog's Gulls in 1995 (D. E. Rábano, pers. obs.).

Banco Nordeste Two colonies were located on the east coast of Banco Nordeste (Figure 1). Both colonies were found near the mouth of a tidal stream with a sandy intertidal area $150 \mathrm{~m}$ wide, partly covered with Spartina densiflora. Nests were placed on the inland side of a $10 \mathrm{~m}$ wide beach of sand and gravel, with the latter substrate covered by patches of Salicornia sp. and Limonium sp. Vegetation consisting mainly of Atriplex bushes covered the sectors at a higher elevation above water level adjacent to the beach. Therefore, nests were placed only a few metres from the high tide mark $(1-6 \mathrm{~m})$ and from vegetation $(1-1.5 \mathrm{~m})$. The colonies at Banco Nordeste were located 100-150 m apart. Kelp Gull nests were observed a few metres inland from both colonies.

\section{Nest site characteristics}

Olrog's Gulls nested in discrete groups at relatively high densities, which ranged between 0.62 and 1.1 nests $/ \mathrm{m}^{2}$ (Table 2). Even though the overall nesting density of colony 2 at Islote Arroyo Jabalí Oeste was 0.67 nests $/ \mathrm{m}^{2}$, the densities of the two main groups of nests in that colony, which were separated by approximately $4 \mathrm{~m}$, were $1.00(n=15)$ and $1.05(n=52)$ nest/ $\mathrm{m}^{2}$. At this same colony, four nests were found $7 \mathrm{~m}$ away from the main groups of nests, separated from them by a patch of Salicornia sp. with a few Kelp Gull nests. Mean inter-nest distance ranged between 0.61 and $0.76 \mathrm{~m}$ (Table 2). Nesting substrate varied among colonies (Table 2). All nests at colony 1 in Islote Arroyo Jabalí Oeste $(n=17)$ were built on herbaceous vegetation, mostly Salicornia sp. and Frankenia juniperoides. At colony 2 in the same islet, $79.5 \%$ of nests were built on vegetation debris and $20.5 \%$ on low herbaceous vegetation (Salicornia sp. and F. juniperoides) $(n=73)$. At Banco Nordeste all nests were built on gravel and sand. All nests sampled at the 
Table 2. Characteristics of nest sites of Olrog's Gulls breeding at Bahía San Blas, Buenos Aires Province

\begin{tabular}{|c|c|c|c|c|}
\hline & \multicolumn{2}{|c|}{ Isla Arroyo Jabalí } & \multicolumn{2}{|c|}{ Banco } \\
\hline & Oeste 1 & Oeste 2 & Nordeste 1 & Nordeste 2 \\
\hline Number of nests sampled & 17 & $69^{a}$ & 29 & 171 \\
\hline Nesting substrate & Herbs $^{b}$ & Debris and herbs & Gravel, sand & Gravel, sand \\
\hline Nest diameter (external) $(\mathrm{cm})$ & $34.59 \pm 3.62$ & $40.70 \pm 4.64$ & $43.76 \pm 4.01$ & ND \\
\hline Nest diameter (internal) (cm) & $18.76 \pm 1.75$ & $18.79 \pm 1.29$ & $22.59 \pm 1.80$ & ND \\
\hline Nesting material & Debris & Debris & Debris & Debris \\
\hline Distance to nearest nest $(\mathrm{m})$ & $0.76 \pm 0.28$ & $0.61 \pm 0.17$ & $0.64 \pm 0.17$ & ND \\
\hline Density (nests $/ \mathrm{m}^{2}$ ) & 0.62 & $0.67^{c}$ & 1.10 & ND \\
\hline
\end{tabular}

a Sample excludes four nests separated from main group.

${ }^{b}$ Salicornia sp. and Frankenia juniperoides.

${ }^{c}$ See text.

$\mathrm{ND}$, No data; values are mean $\pm \mathrm{SD}$.

four colonies $(n=305)$ were built with vegetation debris, mainly Spartina densiflora and some Salicornia sp.. Some nests showed a significant amount of nesting material, reaching up to $15 \mathrm{~cm}$ high. At Islote Arroyo Jabalí Oeste, nests were less developed in colony 1 than at colony 2.

Mean external and internal diameter of nests were $40.57 \pm 5.14$ and $19.71 \pm$ $2.21 \mathrm{~cm}(n=119)$, respectively. Nest size, as indicated by external diameter, was significantly different among colonies (Kruskal-Wallis test: $H=38.14, P<0.0001$ ). Nest occupation and number of eggs per nest varied among colonies (Table 3 ).

\section{Discussion}

Two colonies not previously recorded and a higher total number of breeding pairs than in the 1995 survey (Yorio et al. 1997) were found in the study area during 1998. The two colonies found at Banco Nordeste were not sighted during the surveys in 1990 (Yorio and Harris 1992). The other two colonies were located at the same islet within the Arroyo del Jabalí as in 1995. While in that season gulls bred in a single colony they were found breeding at two separate sites during the course of this study. However, only half of the total number of nests recorded in the islet during 1995 (199 nests) was counted. The colony at Isla Gama, recorded in 1990 but not found in 1995, was also not seen in 1998.

Table 3. Nest contents of Olrog's Gulls breeding at Bahía San Blas, Buenos Aires Province, during 1998

\begin{tabular}{llll}
\hline Breeding site & $\begin{array}{l}\text { Mean number of eggs } \\
\text { per nest }\end{array}$ & $\%$ empty & $\begin{array}{l}\text { Number of nests } \\
\text { sampled }\end{array}$ \\
\hline Islote Arroyo Jabalí Oeste 1 & $0.41 \pm 0.60$ & 64.7 & $(n=17)$ \\
Islote Arroyo Jabalí Oeste 2 & $0.96 \pm 0.75$ & 30.1 & $(n=73)$ \\
Banco Nordeste 1 & $1.10 \pm 0.84$ & 27.6 & $(n=29)$ \\
Banco Nordeste 2 & $1.89 \pm 0.76$ & 4.7 & $(n=171)$ \\
\hline
\end{tabular}


Colony sizes obtained are minimum estimates, as some pairs probably settled and laid after the colonies were surveyed. Colonies were visited 10 days earlier than in 1995, and the number of empty nests or with incomplete clutches suggest that laying and settlement might not have been completed by the time the area was surveyed. Studies at a colony at Caleta Malaspina, Chubut, showed that Olrog's Gulls nest asynchronously, with new nests being started over several weeks (P.Y. and P. García Borboroglu, unpubl. data). Thus, the difference in the timing of the survey between 1995 and 1998 could partly account for the lower number of nests recorded in the latter season. The differences observed in nest occupation, number of eggs per nest and degree of nest building between sites also suggests the existence of differences in the timing of breeding among colonies within the studied breeding season.

However, some of the birds that bred in Isla Arroyo Jabalí Oeste may have moved to breed at Banco Nordeste. Factors determining movement between breeding sites, as has been previously observed in this species (Yorio et al. 1997), cannot easily be determined, although human disturbance cannot be ruled out. The Bahía San Blas area is subject to relatively intense human pressure, including recreation and fishing. Signs of human presence were recorded on the islets at Arroyo del Jabalí, and interviews with local people indicated that visitors have access to the colonies, which are only $4.5 \mathrm{~km}$ from the town of San Blas. In addition, local fishermen mentioned that egging occurs at the Islote del Jabalí colonies, as was previously recorded by Devillers (1977). Although Olrog's Gull colonies at Banco Nordeste are located near a hut occasionally used by sport fishermen, visitation to this site is much more difficult and infrequent than at islets within Arroyo del Jabalí. Although most likely a result of differences in the timing of breeding, the lower average number of eggs per nest and a higher number of empty nests at colonies located in Islote del Jabalí Oeste than those at Banco Nordeste may also be a consequence of human disturbance. The colonies at Islote del Jabalí Oeste are located outside the boundaries of the Bahía San Blas Provincial Reserve, and therefore reserve size should be extended in order to include these breeding sites. In the meanwhile, management guidelines should be developed by the San Blas authorities to minimize access by people to these colonies.

Olrog's Gulls nest at relatively high densities, as has been previously reported by Devillers (1977). The dense nesting observed in the San Blas area is a common feature of Olrog's Gull colonies throughout its breeding range (P.Y., pers. obs.). Comparably high nesting densities have been recorded for only a few gull species, such as Dolphin Gull Larus scoresbii (Yorio et al. 1996), Black-billed Gull L. bulleri and Red-billed Gull L. novaehollandiae scopulinus (Beer 1966), Black-headed Gull L. ridibundus (Burger 1977), and Heermann's Gull L. heermanni (Velarde 1999).

Although some nests were found close to vegetation, all nests were built in open areas. In addition, except for the small colony at Islote Jabalí Oeste, which was situated on low herbaceous vegetation, all nests were on bare ground. Although quantitative information on Kelp Gull habitat and nest site characteristics were not collected, it appears that this species differs in the characteristics of its nesting habitat from Olrog's Gull. Many Kelp Gull nests at all colonies in the study area were located more inland and among Atriplex 
bushes and grasses. Kelp Gulls breeding in coastal Chubut show preference for areas with some vegetation cover (Yorio et al. 1995, P. García Borboroglu and P.Y., unpubl. data). Therefore, it appears that Olrog's Gulls use open habitat while Kelp Gulls use areas of the islet with higher vegetation cover, although Kelp Gulls also nest in the open, indicating some degree of overlap between the species. Further studies are needed to assess habitat partitioning between these two birds, particularly considering that they nest in association at all breeding locations in coastal Argentina (Yorio et al. 1997) and that Kelp Gulls have shown an important population increase in recent decades (Yorio et al. 1998).

\section{Acknowledgements}

We thank Centro de Estudios Ambientales para la Planificación y el Desarrollo and Wildlife Conservation Society for the support to conduct this study. We also thank Prefectura Naval Argentina, Subprefectura Patagones, for logistical support and Estela María Aramayo (Universidad Nacional del Sur) for the identification of plant species. Thanks also to Flavio Quintana and Pablo García Borboroglu for helpful comments on the manuscript.

\section{References}

Beer, C. G. (1966) Adaptations to nesting habitat in the reproductive behaviour of the Black-billed Gull Larus bulleri. Ibis 108: 394-410.

Burger, J. (1977) Role of visibility in nesting behavior of Larus gulls. J. Comp. Physiol. Psychol. 91: 1347-1358.

Collar, N. J., Crosby, M. J. and Stattersfield, A. J. (1994) Birds to watch 2: the world list of threatened birds. Cambridge, U.K.: BirdLife International (BirdLife Conserv. Ser. 4).

Devillers, P. (1977) Observations at a breeding colony of Larus (belcheri) atlanticus. Gerfaut 67: 22-43.

Herrera, G. O. (1997) Dieta reproductiva de la Gaviota de Olrog Larus atlanticus en la Provincia del Chubut. Licenciatura thesis, Universidad Nacional de la Patagonia.

Olrog, C. C. (1967) Breeding of the Band-tailed gull (Larus belcheri) on the Atlantic coast of Argentina. Condor 69: 42-48.

Parker, T. E. III, Stotz, D. F. and Fitzpatrick, J. W. (1996) Ecological and distributional databases. In D.F. Stotz, J.W. Fitzpatrick, T.A. Parker III and D.K. Moskovits, eds. Neotropical birds: ecology and conservation. Chicago: University of Chicago Press.

Velarde, E. (1999) Breeding biology of Heermann's gulls on Isla Rasa, Gulf of California, Mexico. Auk 116: 513-519.

Yorio, P. and Harris, G. (1992) Actualización de la distribución reproductiva, estado poblacional y de conservación de la Gaviota de Olrog (Larus atlanticus). El Hornero 13: 200202.

Yorio, P., Bertellotti, M. and Quintana, F. (1995) Preference for covered nest sites and breeding success in Kelp Gulls Larus dominicanus. Mar. Orn. 25: 121-128.

Yorio, P., Swann, S. and Boersma, P. D. (1996) Breeding biology of the Dolphin Gull (Larus scoresbii) at Punta Tombo, Argentina. Condor 98: 208-215.

Yorio, P., Punta, G., Rábano, D., Rabuffetti, F., Herrera, G., Saravia, J. and Friedrich, P. (1997) Newly discovered breeding sites of Olrog's Gull Larus atlanticus in Argentina. Bird Conserv. Internatn. 7: 161-165. 
Yorio, P., Bertellotti, M. Gandini, P. and Frere, E. (1998) Kelp Gulls (Larus dominicanus) breeding on the Argentine coast: population status and a review of its relationship with coastal management and conservation. Mar. Orn. 26: 11-18.

\section{PABLO YORIO}

Centro Nacional Patagónico and Wildlife Conservation Society, Bv. Brown s/n, 9120, Puerto Madryn, Chubut, Argentina.E-mail: yorio@cenpat.edu.ar

DANIEL E. RÁBANO and PABLO FRIEDRICH

Centro de Estudios Ambientales para la Planificación y el Desarrollo. Sarmiento 230, 5 Piso, 80oo, Bahía Blanca, Buenos Aires, Argentina. E-mail: ceapyd@mixmail.com 